\title{
Multimedia Learning Module (MLM) with Hologram Simulation to Improve Diagrammatic Representation Skills of Students
}

\author{
Mochtar Purwo Nugroho ${ }^{1, *}$ Wipsar Sunu Brams Dwandaru ${ }^{2}$ Arum Mawardani ${ }^{1}$ \\ ${ }^{1}$ Master of Physics Education, Faculty of Mathematics and Natural Sciences, Universitas Negeri Yogyakarta, \\ Indonesia \\ ${ }^{2}$ Department of Physics Education, Faculty of Mathematics and Natural Sciences, Universitas Negeri \\ Yogyakarta, Indonesia \\ "Corresponding author.Email: mochtarpurwo.2019@student.uny.ac.id
}

\begin{abstract}
This research aims to determine the achievement of students' scores after using Multimedia Learning Modules (MLMs) and to determine the increase in diagram representation after using Multimedia Learning Module (MLM). This research uses a pre-experimental design with one group pre-test and post-test design. The data collection technique used was purposive sampling. The sample used was 35 students from class X IPA 3. The research instrument used was multiple choice test questions containing achievement indicators. The results showed an increase in the ability to represent diagrams in the medium category as indicated by the $\mathrm{N}$-Gain value.
\end{abstract}

Keywords: Multimedia learning module (MLM), Hologram, Diagrammatic representation skills

\section{INTRODUCTION}

Representation is used by students to organize knowledge in thinking processes [1]. In addition, students can solve physics problems using diagrammatic representations by drawing diagrams [2]. In general, coding a number of data as a basis for knowledge by humans and computers as a form of diagrammatic representation [3]. Diagram representation makes it easier for students to interpret problems and build a deeper understanding of natural phenomena [4]. Students usually use diagrammatic representations to explain words in the form of images in understanding problem situations [5]. Diagram representation is superior and even considered more exclusive when compared to verbal representation when solving problems in physics [6]. Therefore, the ability to represent diagrams determines the success of students in solving problems in certain concepts related to figure and vectors

Diagram representation has advantages over verbal representation in solving physics problems [7]. A diagram can gather all the information used and can be a conclusion from the opinion [8]. In addition to quantitative problems, students can solve qualitative problems using diagrams [9]. This happens because students can make pictures and arrows as a certain vector direction [10]. So physics problems can be solved using diagrammatic representation capabilities

Physics learning is difficult for students to understand due to several factors. Students experience learning difficulties due to low motivation and potential factors [11]. Learning difficulties are not all due to the influence of the level of intelligence of students, but because psychological factors also play a role. interviews can be conducted to determine the influence of psychological factors. In working on students, sometimes they are less motivated and not focused so that the results of learning physics are not satisfactory. In addition, most of the physics material is in the form of concepts that are difficult to understand by students so that it requires high imagination to understand [12]. Teachers in explaining a physics concept use many words and students are not challenged to use other representations in the form of images, graphs, or mathematics from a physics concept being taught [13]. The weak ability of students to represent data is the cause of the difficulty of students in solving physics problems [14]. 
The main source of knowledge comes from the teacher and usually students are only provided with physics books to increase understanding of physics concepts. It happened in the conventional class. Students are required to read physics books without being equipped with supporting multimedia [15]. Learning media equipped with multimedia can be used to support and improve students' understanding of physics concepts [16]. So learning difficulties from students can be overcome by using multimedia assisted learning media. There are many instructional media that can be used by teachers, one of which is through multimedia learning module (MLM). Schools must have computer facilities equipped with supporting applications for making MLM. MLM are effectively used to improve students' basic understanding because they are equipped with narrative text and flash animation or simulations that display the concepts of physics [15]. To make it easier for students, learning media can be accessed online using a computer so that students will be free to learn and be flexible in accessing [17].

Technology is able to help students understand physics material, one of which is holograms. The use of 3D holograms can overcome the barriers of students in understanding learning both in class and practice [18]. The visual 3D hologram display can replace real equipment to be used as practice, making it easier for teachers to prepare physics equipment. 3D holograms can be made using the concept of the reflection generated by the LED / light from the LCD [19]. Holograms need to be developed as learning media because not all learning objects can be faced directly by students [20]. Therefore, the use of 3D holograms can help students to improve their diagrammatic representation skills.

This paper will discuss the use of instructional media to solve the above problems. The learning media that has been developed is a Multimedia Learning Module (MLM) equipped with a 3D hologram. MLM is used to improve student diagram representation.

\section{RESEARCH METHODS}

This research is a quantitative research with experimental methods. The design used was preexperimental with one group pre-test and post-test design. The design was chosen because of the limitations of students who used only 1 class. The research design is shown in Figure 1.

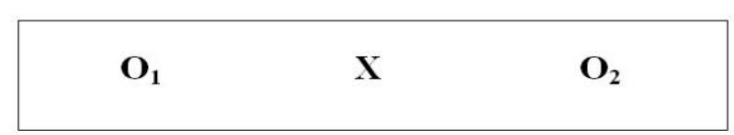

Figure 1 One group pre-test and post-test design

With O1: pretest, $\mathrm{X}$ : treatment/ implementation MLM with hologram simulation, dan $\mathrm{O} 2$ : posttest.

The research was conducted in April 2020 at SMA Negeri 1 Muntilan. Purposive sampling was used to determine the research sample. The research sample consisted of 35 students from class X MIPA 3. The research instruments used were Multimedia Learning Modules (MLM) and test questions. The test is in the form of multiple choices consisting of 5 questions that students must answer. The test contains questions about understanding diagrams on harmonic motion material Test questions are made based on the indicators to be studied

The data analysis technique is divided into two, namely instrument validation and descriptive analysis of research results. Instrument validation is used to see the feasibility of the MLM instrument. The instrument was analyzed using the Aiken $\mathrm{V}$ equation as follows:

$\mathrm{V}=\frac{\Sigma \mathrm{s}}{[\mathrm{n}(\mathrm{c}-1)]}$

$\mathrm{s}$ is $\mathrm{r}-\mathrm{l}_{0}, \mathrm{l}_{0}$ is the lowest validity rating score, $\mathrm{c}$ is the highest validity rating score, $r$ is score given by the validator. The validation score obtained from the media expert validator and the material expert will be included in the Aiken V criteria according to table 1 [21].

Table 1. Validation criteria

\begin{tabular}{|c|c|}
\hline Validity Result & Validity Criteria \\
\hline $0.8<\mathrm{V} \leq 1$ & Very Adequate \\
\hline $0.6<\mathrm{V} \leq 0.8$ & Adequate \\
\hline $0.4<\mathrm{V} \leq 0.6$ & Less Adequate \\
\hline $0.2<\mathrm{V} \leq 0.4$ & Inadequate \\
\hline
\end{tabular}

Descriptive analysis of the results of the study was carried out using the pretest and posttest value data obtained by students. Data from the pretest and posttest results were analyzed by means of the mean / average value of the class and using Normalized Gain to see the increase in the pretest to posttest scores. The equation used for Normalized Gain is as follows:

$\mathrm{N}$-gain $=\frac{\mathrm{S}_{\text {post }}-\mathrm{S}_{\text {pre }}}{\mathrm{S}_{\max }-\mathrm{S}_{\text {pre }}} \times 100 \%$ 
The results of the Normalized Gain calculation are included in the criteria in table 2 below [22]:

Table 2. Classification of gain score

\begin{tabular}{|c|c|}
\hline Interval & Category \\
\hline$<\mathrm{g}>\geq 0.7$ & High \\
\hline $0.7><\mathrm{g}>\geq 0.3$ & Medium \\
\hline$<\mathrm{g}><0.3$ & Low \\
\hline
\end{tabular}

\section{RESULTS AND DISCUSSION}

\subsection{Result}

The implementation of MLM with holographic simulations on Harmonious Motion material is carried out in class X semester II. The research MLM media has been validated by expert judgment, the results are shown in table 3 .

Table 3. MLM media validation results

\begin{tabular}{|l|c|c|c|}
\hline No & $\begin{array}{c}\text { MLM } \\
\text { Validation } \\
\text { Aspects }\end{array}$ & Score & Criteria \\
\hline 1. & Media & 0,86 & $\begin{array}{l}\text { Valid (Very } \\
\text { Adequate) }\end{array}$ \\
\hline 2. & Material & 0,88 & $\begin{array}{l}\text { Valid (Very } \\
\text { Adequate) }\end{array}$ \\
\hline
\end{tabular}

Table 3 shows that MLM media has valid criteria in terms of media aspects and material aspects. MLM media can be used for learning. MLM with holographic simulations that have been developed can be seen in figure 2 .

Students work on pretest questions to find out their initial abilities. Students independently learn physics material at home by opening MLM via android. Holograms are used by students to observe simple pendulum motion and spring motion. After finishing learning to use MLM, students work on posttest questions.

The student's diagrammatic representation ability was measured using the instrument from 5 multiple choice questions that had been given during the pretest and posttest. The analysis was carried out using NGain based on the pretest and posttest values. Table 2 describes the results of the pretest and posttest analysis of the diagram representation ability.
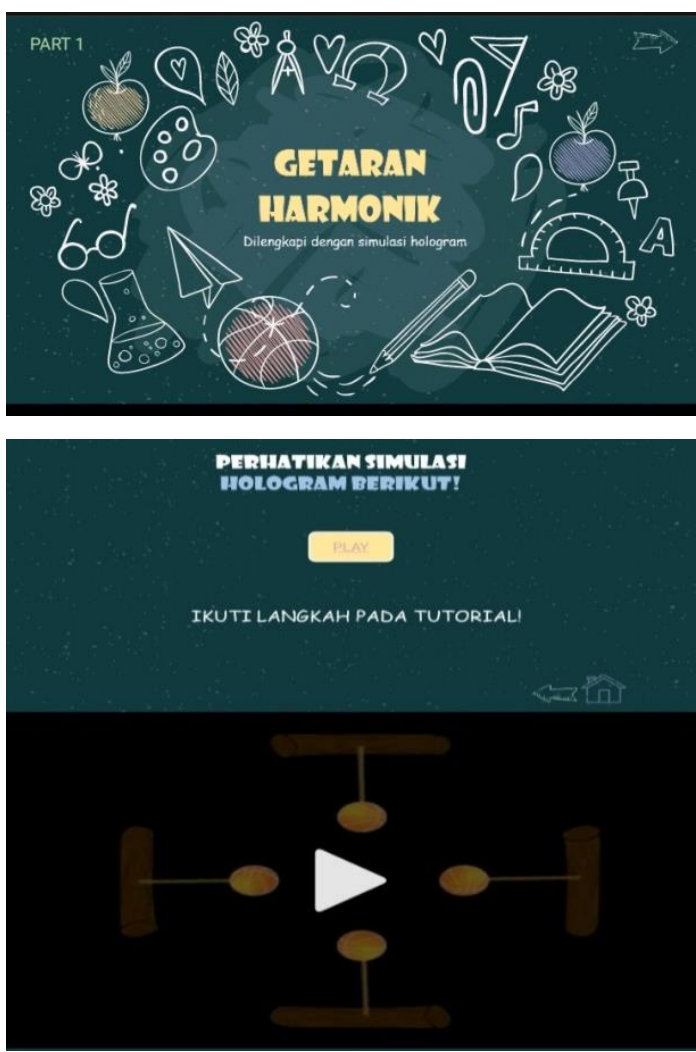

Figure 2 MLM with hologram simulation

Table 4. Results of diagrammatic representation ability test

\begin{tabular}{|c|c|c|}
\hline Category & Pre-Test & Post-Test \\
\hline Minimum score & 0 & 20 \\
\hline Maximum score & 90 & 100 \\
\hline Mean & 53 & 81 \\
\hline N-Gain & \multicolumn{2}{|c|}{0.6} \\
\hline
\end{tabular}

Table 4 shows the descriptive analysis and the average value of the diagram representation ability, the pretest average is 53 and the posttest average is 81 . An increase in the ability of diagram representation can be observed at the $\mathrm{N}$-gain value of 0.6 in the moderate category according to Table 2. Figure 3 shows how the ability of diagram representation increases. The red color shows the pretest results while the blue color shows the postest results. It can be seen from the figure that the post-test results are higher than the pretest results. 


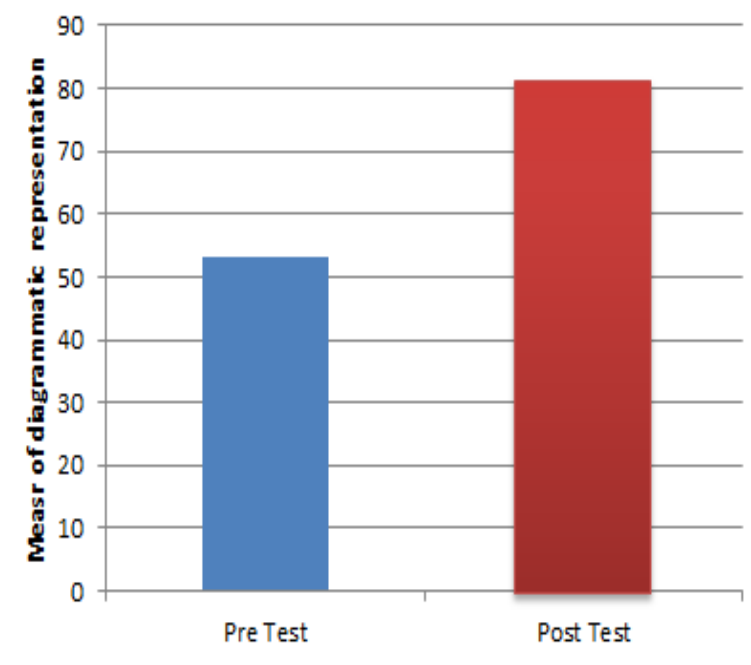

Figure 3 Means of diagrammatic representation ability test

\subsection{Discussion}

The use of MLM equipped with 3D holograms can be applied in learning to improve students' diagrammatic representation skills. Learning media are prepared based on the 2013 curriculum for class X semester II. The contents of the MLM material are harmonic vibrations on the pendulum, harmonic vibrations on the spring, and holographic videos.

In learning, students must prepare a hologram projector. The hologram projector is made of mica plastic. Students make a hologram projector according to the pattern and size prepared by the teacher. The hologram projector used is a pyramid shape. After that, the hologram projector will be used to view and observe the hologram video on each student's cellphone. The hologram video consists of 2 videos, namely, the harmonic motion of the pendulum and the harmonic motion of the spring. Students can observe the harmonic motion diagram from the video. Therefore, hologram videos will stimulate and improve students' diagrammatic representation skills.

The student's representation ability will be assessed using test questions consisting of 5 questions. Before students do the learning, students will work on pretest questions. Then students will learn programming languages using media and $3 \mathrm{~d}$ holograms prepared by the teacher. After that, students will work on postest questions. The results of the pretest and posttest scores will be used to see an increase in the ability to represent diagrams.

The results of the data analysis show that the implementation of MLM equipped with 3D holograms can improve students' diagrammatic representation skills as shown in Table 4 . The ability to represent diagrams is measured using multiple choice questions. The diagrammatic representation ability is quite good, it can be seen from the N-Gain value in the medium category. The increase in the category is moderate because students learn independently at home. Lack of direct supervision from the teacher during the learning process causes an increase in the representation ability of students not in the high category. Weaknesses are still found, students are still confused about determining the direction of the observed physical quantities.

This research is in line with the results of research by Sadaghiani [15],[17] which explains that the use of MLM can increase motivation, student activity and practicality in learning. The results of the research by Hendra [18] showed that with holograms the students better understood the shapes of objects or physical symptoms in 3D and increased the students' ability to represent diagrams.

\section{CONCLUSION}

The conclusion of this research is that the implementation of MLM with hologram simulation can improve the ability of diagram representation. For further research, learning can use other physics materials and making holograms with other methods.

\section{REFERENCES}

[1] L. Franco, E.T. Rolls, N.C. Aggelopoulos, J.M. Jerez, Neuronal Selectivity, Population Sparseness, and Ergodicity in The Inferior Temporal Visual Cortex, Biological Cybernetics 96(6) (2007) 547-560. DOI: https://doi.org/10.1007/s00422-007-0149-1

[2] T. Gok, The General Assessment of Problem Solving Processes and Metacognition in Physics Education, Eurasian Journal of Physics and Chemistry Education 2(2) (2010) 110-122. DOI: https://doi.org/10.51724/ijpce.v2i2.186

[3] Z. Kulpa, Diagrammatic Interval Analysis with Applications, Instytut Podstawowych Problem Techniki Polskiej Akademii Nauk, 2006.

[4] D. Mc Padden, E. Brewe, Impact of The Second Semester University Modeling Instruction Course on Students' Representation Choice, Physical Review Special Topics-Physics Education Research 13(1) (2017) 1-15. DOI: https://doi.org/10.1103/PhysRevPhysEducRes.1 3.020129 
[5] D. Rosengrant, E. Etkina, A.V. Heuvelen, An overview of recent research on multiple representations, in: AIP Conference Proceedings, vol. 883, AIP Publishing, College Park, Maryland, 2006, pp. 149-152. DOI: https://doi.org/10.1063/1.2508714

[6] A. Maries, C. Singh, Exploring pedagogical content knowledge of physics instructors and teaching assistants using the force concept inventory, in: AIP Conference Proceedings, vol. 2109, AIP Publishing, College Park, Maryland, 2013, pp. 1-46. DOI: https://doi.org/10.1063/1.5110146

[7] A. Maries, C. Singh, To use or not to use diagrams: the effect of drawing a diagram in solving introductory physics problem, in: AIP Conference Proceedings, vol. 1513, AIP Publishing, College Park, Maryland, 2013, pp. 282-285.

DOI:

https://doi.org/10.1063/1.4789707

[8] J. Larkin, H. Simon, Why A Diagram Is (Sometimes) Worth Ten Thousand Words, Cognitive Science, 11(1) (1987) 65-99. DOI: https://doi.org/10.1111/j.15516708.1987.tb00863.x

[9] A. Savinainen, A. Makynen, P. Nieminen, J. Viri, Does Using A Visual-Representation Tool Foster Students Ability to Identify Forces and Construct Free-Body Diagrams, Physical Review Special Topics Physics Education Research 9(1) (2013) $1-11$.

DOI: http://dx.doi.org/10.1103/PhysRevSTPER.9.010 $\underline{104}$

[10] A.F. Heckler, Some Consequences of Prompting Novice Physics Students to Construct Force Diagrams, International Journal of Science Education 32(14) (2010) 1829-1851. DOI: https://doi.org/10.1080/09500690903199556

[11] A.D. Saputro, Aplikasi Komik Sebagai Media Pembelajaran, MUADDIB, 2015.

[12] W.S. Hadi, P. Dwijananti, Pengembangan Komik Fisika Berbasis Android Sebagai Suplemen Pokok Bahasan Radioaktivitas Untuk Sekolah Menengah Atas, Unnes Physics Education Journal 4(2) (2015) 15-24. DOI: https://doi.org/10.15294/upej.v4i2.7431

[13] S. Monika, Abdurrahman, W. Suana, Pengaruh Kemampuan Membangun Mode Representasi terhadap Pemecahan Masalah Fisika dengan Menerapkan Inkuiri Terbimbing, Jurnal Pembelajaran Fisika 2(4) (2014) 131-143.

[14] S. Selamet, K.I. Mahardika, B. Supriadi, Analisis kemampuan representasi verbal, matematika, gambar dan grafik (r-vmgg) siswa SMAN Pasirian pada materi termodinamika: in FKIP eProceeding, vol. 3, Universitas Jember, Jember, 2018, pp. 144-48.

[15] H.R. Sadaghiani, Controlled Study on The Effectiveness of Multimedia Learning Modules for Teaching Mechanics, Physical Review Special Topics - Physics Education Research 8(1) (2012) 1-7. DOI: https://doi.org/10.1103/PhysRevSTPER.8.0101 $\underline{03}$

[16] Z. Chen, G. Gladding, How to Make A Good Animation: A Grounded Cognition Model of How Visual Representation, Physical Review Special Topics - Physics Education Research 10(1) (2014) 1-24. DOI: https://doi.org/10.1103/PhysRevSTPER.10.010 $\underline{111}$

[17] H.R. Sadaghiani, Using Multimedia Learning Modules in A Hybrid-Online Course in Electricity and Magnetism, Physical Review Special Topics - Physics Education Research 7(1) (2011) 1-7. DOI: https://doi.org/10.1103/PhysRevSTPER.7.0101 $\underline{02}$

[18] H. Jaya, L. Taris, Teknologi Holografi untuk Pembelajaran Virtual pada Sekolah Menengah Kejuruan, Jurnal Elektronika Telekomunikasi \& Computer 5(1) (2010) 783-781.

[19] Arifah, M. Azam, K.S. Firdausi, Pembuatan Hologram Refleksi, Berkala Fisika 10(3) (2007) 127-135.

[20] Y. Soepriyanto, Sihkabudeb, E. Surahman, Pengembangan Obyek 3D Digital pada Meja Piramida Hologram untuk Pembelajaran Kelas, Jurnal Kajian Teknologi Pendidikan 1(4) (2018) 333-339.

[21] N. Sholihah, I. Wilujeng, A. Gebze, S. Purwanti, Development of android-based learning media on light reflection material to improve the critical thinking skill of high school students, in: Journal of Physics:Conferens Series, vol. 1440, IOP Publishing, Bristol, 2020, pp. 1-6. DOI: https://doi.org/10.1088/17426596/1440/1/012034

[22] R. Hake, Interactive-Engagement Vs. Traditional Methods: A Six-Thousand Student Survey of Mechanics Test Data for Introductory Physics Courses, American Journal of Physics 66(1) (1998) 64-74. DOI: https://doi.org/10.1119/1.18809 